San Jose State University

SJSU ScholarWorks

Master's Theses

Master's Theses and Graduate Research

1999

\title{
Reproductive biology and growth of Anthomastus ritteri (Octocorallia:alcyonacea)
}

Erik E. Cordes

San Jose State University

Follow this and additional works at: https://scholarworks.sjsu.edu/etd_theses

\section{Recommended Citation}

Cordes, Erik E., "Reproductive biology and growth of Anthomastus ritteri (Octocorallia:alcyonacea)" (1999). Master's Theses. 1866.

DOI: https://doi.org/10.31979/etd.mjv6-vwgn

https://scholarworks.sjsu.edu/etd_theses/1866

This Thesis is brought to you for free and open access by the Master's Theses and Graduate Research at SJSU ScholarWorks. It has been accepted for inclusion in Master's Theses by an authorized administrator of SJSU ScholarWorks. For more information, please contact scholarworks@sjsu.edu. 


\section{INFORMATION TO USERS}

This manuscript has been reproduced from the microfilm master. UMI films the text directly from the original or copy submitted. Thus, some thesis and dissertation copies are in typewriter face, while others may be from any type of computer printer.

The quality of this reproduction is dependent upon the quality of the copy submitted. Broken or indistinct print, colored or poor quality illustrations and photographs, print bleedthrough, substandard margins, and improper alignment can adversely affect reproduction.

In the unlikely event that the author did not send UMI a complete manuscript and there are missing pages, these will be noted. Also, if unauthorized copyright material had to be removed, a note will indicate the deletion.

Oversize materials (e.g., maps, drawings, charts) are reproduced by sectioning the original, beginning at the upper left-hand comer and continuing from left to right in equal sections with small overlaps. Each original is also photographed in one exposure and is included in reduced form at the back of the book.

Photographs included in the original manuscript have been reproduced xerographically in this copy. Higher quality $6^{\prime \prime} \times 9^{n}$ black and white photographic prints are available for any photographs or illustrations appearing in this copy for an additional charge. Contact UMI directly to order.

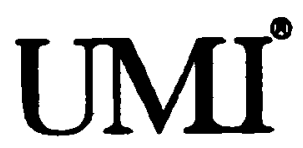

Bell \& Howell Information and Learning 300 North Zeeb Road, Ann Arbor, MI 48106-1346 USA 800-521-0600 

REPRODUCTIVE BIOLOGY AND GROWTH OF

ANTHOMASTUS RITTERI (OCTOCORALLIA:ALCYONACEA)

\author{
A Thesis \\ Presented to \\ The Faculty of Moss Landing Marine Laboratories \\ San Jose State University
}

In Partial Fulfillment

of the Requirements for the Degree

Master of Science

by

Erik E. Cordes

August 1999 
OMI Number: 1396167

UMI Microform 1396167

Copyright 1999, by UMI Company. All rights reserved.

This microform edition is protected against unauthorized copying under Title 17, United States Code.

\section{UMI}

300 North Zeeb Road

Ann Arbor, MI 48103 
(C) 1999

Erik E. Cordes

ALL RIGHTS RESERVED 
APPROVED FOR THE DEPARTMENT OF BIOLOGICAL SCIENCES
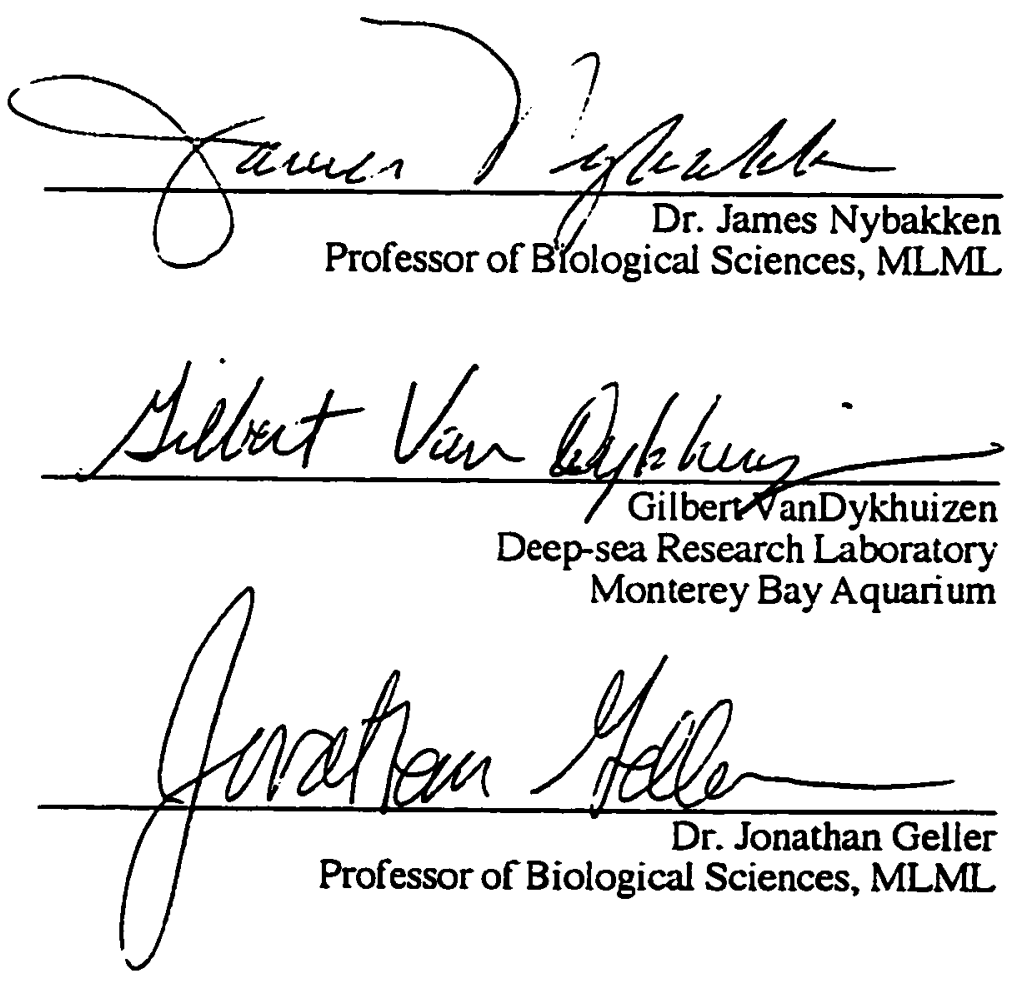

APPROVED FOR THE UNIVERSITY William Pish 


\section{ABSTRACT \\ LABORATORY INVESTIGATIONS OFTHE REPRODUCTIVE BIOLOGY AND GROWTH OF ANTHOMASTUS RITTERI (OCTOCORALLIA:ALCYONACEA) FROMMONTEREY BAY \\ by Erik E. Cordes}

Anthomastus ritteri Nutting, 1909 is a deep-sea alcyonacean from the Pacific coast of California, U.S.A. and Baja California, Mexico. Laboratory specimens were studied with respect to their reproductive biology, larval settlement behavior, and growth rates. Collected $A$. ritteri colonies were dioecious larval brooders that exhibited continuous reproduction. Developing larvae were brooded in the siphonozooids of the colony. Demersal planula larvae crawled away from female colonies, or were swept away by currents. Larvae settled on hard substrates covered by an organic film between 2 and 123 days after release. A Gompertz growth model was based on size specific growth rates of 15 colonies. Growth was slow for the first 1-2 years as additional autozooids formed. When colonies were comprised of 3-4 feeding polyps, growth rates increased. Growth slowed in adult colonies, approaching an asymptotic size between 25 and 30 years of age. 


\section{ACKNOWLEDGMENTS}

I express my gratitude to my committee members Dr. James Nybakken, Gilbert VanDyhuizen, and Dr. Jonathan Geller for their guidance, inspiration, wisdom, and for their critical review of this manuscript. I would also like to thank Sue Lisin and Jason Flores for their assistance during the research and their comments on the paper. I owe many thanks to the Monterey Bay Aquarium and the Deep-sea Research Laboratory in particular for providing valuable lab space and funding the histological preparations. Many thanks to the staff of the Community Hospital of the Monterey Peninsula for the processing of the histological sections.

Many thanks to the faculty, staff, and students of Moss Landing Marine Laboratories. I would like to thank the students of the Invertebrate Zoology lab at Moss Landing Marine Labs for their insightful comments during the preliminary stages of the research. I am indebted to Gail Johnston and Joan Parker for all of their assistance. Special thanks to everyone who has lent their support, assistance, and friendship over the years, especially Ron and Cathy Cordes. 


\section{Page}

List of Tables

vii

List of Figures

viii

INTRODUCTION

1

MATERIALS AND METHODS

RESULTS

Gonadal Development

Larval Settlement and Development

Growth

DISCUSSION

Gonadal Development

Larval Settlement and Development

Growth

CONCLUSIONS

LITERATURE CITED

TABLES

FIGURES 


\section{LIST OF TABLES}

\section{Page}

Table 1. Size of gonads in various stages of development.

Table 2. Results of settlement experiment.

Table 3. Development times for larval and post-larval stages of Anthomastus ritteri. 36 


\section{LIST OF FIGURES}

Page

Figure 1. Location of collection sites in Monterey Bay, California, USA 37

Figure 2. Female reproductive structures of Anthomastus ritteri. 38

Figure 3. Male reproductive structures of Anthomastus ritteri. 39

Figure 4. Regression of stalk diameter to other morphological parameters measured. 40

Figure 5. Growth of four representative Anthomastus ritteri colonies. 41

Figure 6. Composite growth chart of 15 Anthomastus ritteri colonies. 42

Figure 7. Conversion factors for derivation of Gompertz parameters. 43

Figure 8. Gompertz growth functions for Anthomastus ritteri. 44 


\section{Introduction}

Anthomastus ritteri is a temperate deep-sea alcyonacean of the Family Alcyoniidae. It inhabits hard substrates off the coast of California, U.S.A. and Baja California, Mexico from $210-2050 \mathrm{~m}$ depth. There are 22 species within the genus Anthomastus distributed world wide (D'Hondt 1988, D'Hondt 1992). Members of the genus are found in the North Atlantic from the Davis Straight near the polar circle to the Canary Islands in the east, and from Greenland and Newfoundland to the Caribbean in the west. In the Indian Ocean, Anthomastus is found from South Africa and Madagascar to the Cocos Islands and Java. Western Pacific species extend from the Kurile Islands and Japan south to New Zealand and New Caledonia. Isolated populations also occur around Hawaii and off the coast of California, U.S.A., and Baja California, Mexico (D'Hondt 1988, D'Hondt 1992). The depth range of the genus extends from $140 \mathrm{~m}$ in the Grand Banks and the Norwegian fjords to $2859 \mathrm{~m}$ south of the Canary Islands (Jungersen 1927).

A. ritteri colonies are composed of a proximal stalk attached to the substratum and a distal capitulum containing the zooids. The capitulum may be red or white in color. The capitulum is composed of a thin layer of epidermis surrounding a thick mesoglea (coenenchyme). The coenenchyme is a calcium carbonate spicule reinforced collagen matrix surrounding a network of gastrodermal tubes, or solenia. Solenia form a ladderlike network throughout the coenenchyme and an anastomosing network in the stalk tissue. Solenia are responsible for transferring nutrients between zooids. A. ritteri colonies are dimorphic. Autozooids are the feeding polyps, each consisting of an 
anthocodium (eight pinnate tentacles and the pharynx) protruding from the surface of the capitulum, and the gastrovascular cavity extending into the syndete, the coenenchymal portion of the stalk tissue. Siphonozooids contain the reproductive structures and are responsible for controlling water flow within the colony. Stalk tissue is sterile, containing rod-like spicules throughout and double capstan-type spicules at the base.

The original description of $A$. ritteri (Nutting 1909) focused on external morphology and spicule type. The internal anatomy of the genus Anthomastus was described by Jungersen (1927) from preserved specimens of $A$. grandiflorus. The pattern of formation of additional autozooids by the primary polyp of $A$. grandifloris was inferred from a series of preserved juvenile specimens (Jungersen 1927). Recent information on the genus Anthomastus involves the description of the species $A$. tahinodus (D'Hondt 1988) and A. globosus (D'Hondt 1992) as well as remarks concerning the synonymy of certain species (D'Hondt 1988, D'Hondt 1992). Studies of the feeding behavior (Riise 1990, Chadrasekaren 1991), periodicity of polyp contraction (Chadrasekaren 1991), and local distribution (Riise 1990) of $A$. ritteri are contained in unpublished manuscripts at Hopkins Marine Station of Stanford University, Pacific Grove, CA. Detailed information on the reproduction and life history of any species of Anthomastus is non-existent.

Soft corals (Octocorallia: Alcyonacea) are a diverse group of marine invertebrates exhibiting a wide variety of reproductive strategies and growth patterns (Campbell 1974, Benayahu and Loya 1984a, Alino and Coll 1989, Sammarco and Coll 1992). Most of the 
work on this group has focused on tropical reef species (Alino and Coll 1989, Benayahu 1995), with the majority of these studies undertaken in the Red Sea (Benayahu and Loya 1984a, Benayahu and Loya 1984b, Benayahu and others 1989, Benayahu 1991, BenDavid-Zaslow and Benayahu 1996, Benayahu and Schleyer 1998, Dahan and Benayahu 1998, Kruger and others 1998, Ben-David-Zaslow and Benayahu 1998). Temperate octocorals have largely been neglected (Sebens 1983b). Information on the reproductive biology and growth rates of deep-sea invertebrates in general (Gage and Tyler 1985, Gage and Tyler 1991), and cnidarians in particular (Rice and others 1992, Coma and others 1995b) is sparse.

The Alcyonacea exhibit three modes of reproduction: internal brooding of larvae, surface brooding, and broadcast spawning of gametes with external fertilization. Tropical alcyonaceans normally exhibit seasonal spawning of gametes with external fertilization (Benayahu and Loya 1984a, Alino and Coll 1989, Benayahu and others 1989, Benayahu 1991). Reproductive investigations of temperate soft corals suggest continuous gametogenesis, internal fertilization, and brooding of developing embryos as the typical strategy (Hartnoll 1977, Sebens 1983a, Sebens 1983b, Farrant 1986, McFadden 1991). While octocorals in general follow this trend towards brooding in colder climates (Alino and Coll 1989, Coma and others 1995a), mode of reproduction may vary among members of the same genus (Hartnoll 1977), or even within species (Kruger and others 1998). Other reproductive strategies recorded for alcyonaceans include hermaphroditism 
(Benayahu and Loya 1984a, Benayahu 1991, Kruger and others 1998), parthenogenesis (Hartnoll 1977), and asexual reproduction (Benayahu and Loya 1987, McFadden 1991).

Gonadal development follows a similar pattern throughout the Alcyonacea (Benayahu 1991). In monomorphic colonies and dimorphic colonies of the family Xeniidae, gonads form on the mesentarial filaments of autozooids (Sebens 1983b, Benayahu and others 1989, Kruger and others 1998). In contrast, in the genus Anthomastus, siphonozooids contain the reproductive structures (Jungersen 1927). As alcyonacean gonads develop, they detach from the mesenteries and expand to fill the gastrovascular cavity (Benayahu and Loya 1984 a and b, Benayahu and others 1989). Mature oocytes are either retained in brooding species, or released in broadcast spawning forms. Fully developed spermaries burst to release spermatozoa (Benayahu and Loya 1984a; 1984b) or whole spermaries may be released (Benayahu and others 1989).

When fertilization is external in soft corals, planulae have a short planktonic phase (Benayahu and Loya 1987, Alino and Coll 1989). Larvae are lecithotrophic and benthic (demersal) in brooding species (Sebens 1983b, Farrant 1986, McFadden 1991). In corals, including the Alcyonacea (soft corals), Gorgonacea (sea fans and bamboo corals), and Scleractinia (stony corals) (Brusca and Brusca 1990), metamorphosis from planula to polyp proceeds through a series of three steps: 1 . Settlement and attachment to substrate, 2. deposition of a calcium carbonate basal layer, and 3. differentiation into the polypoid form (Richmond 1985). 
A general paucity of information exists on growth rates of temperate soft corals (Sebens 1983b). Few studies of octocoral growth rates have been attempted due to the high degree of environmentally induced variability (Velimirov 1975, Sebens 1979, Mitchell and others 1993, Riegel 1995). Sebens (1983b) followed the growth and survivorship of a cohort of the temperate alcyonacean Alcyonium siderium and found rapid juvenile growth.

Studies of deep-sea invertebrates have become more common over the past 20 years with increased accessibility of the organisms (Gage and Tyler 1991). Information on growth rates of deep-sea organisms exists for echinoids (Gage and Tyler 1985, Gage 1987), ophiuroids (Gage and Tyler 1981, Gage 1990), mysid shrimp (Childress and Price 1978), barnacles (Lampitt 1990), bivalves (Hutchings and Haedrich 1984, Gilkinson and others 1986), aplacophoran molluscs (Sheltema 1987), and brachiopods (Zezina 1975). Information on deep-sea cnidarian growth rates is derived from a single species of gorgonian from the Mediterranean, Paramuricea clavata (Coma and others 1995b). This is a long lived species which exhibited a slow increase in overall height $(1.8 \mathrm{~cm}$ per year) during the two year study. In general, it is believed that most deep-sea species fit this pattern of slow growth and great longevity (Gage and Tyler 1991).

The purpose of this study was to describe the processes of gametogenesis, larval and post - larval development in Anthomastus ritteri. Substratum selection by planula larvae was examined in laboratory experiments. In addition, a growth model for $A$. ritteri based on laboratory data was developed. 


\section{Materials and Methods}

Anthomastus ritteri Nutting, 1909, colonies were collected by Monterey Bay Aquarium and Monterey Bay Aquarium Research Institute (MBARI) staff using the ROV Ventana aboard the vessel RV Pt. Lobos. Collections were made primarily at two sites. The first site was offshore of Cypress Point, Carmel ( $36^{\circ} 34^{\prime} 59^{\prime \prime} \mathrm{N}, 122^{\circ} 00^{\prime} 39^{\prime \prime}$ W) at approximately $300 \mathrm{~m}$ (Fig. 1). The second was the "Jelly Wall" site in the Monterey Submarine Canyon near Soquel Canyon $\left(36^{\circ} 45^{\prime} 22^{\prime \prime} \mathrm{N}, 121^{\circ} 58^{\prime} 18^{\prime \prime} \mathrm{W}\right)$ at $450 \mathrm{~m}$ depth (Fig. 1). Colonies were maintained in $200 \mathrm{~L}$ aquaria at the Monterey Bay Aquarium in a semi-closed seawater system at $6.0^{\circ} \mathrm{C}, 1 \mathrm{ATM}$ pressure and ambient laboratory oxygen levels. A. ritteri colonies were fed frozen krill (Euphausia pacifica) and adult brine shrimp (Artemia sp.) 3 to 4 times a week.

Specimens for dissections were fixed in $10 \%$ formalin for 24 hours then transferred to $70 \%$ ethanol for preservation. Ten tissue samples were taken from $5 \mathrm{~A}$. ritteri colonies for histological investigations. Tissue samples were processed at the Community Hospital of Monterey Peninsula using an auto processor (LX120 tissue processor) following standard histological methodology. A dehydration series through ethanol and xylene followed by three changes of paraffin took place under vacuum within the auto processor. Samples were embedded in $58^{\circ} \mathrm{C}$ paraffin on a cold plate. Thin sections $(5 \mu \mathrm{m})$ were cut and floated on a water bath containing adhesive. Sections were placed on microscope slides on a hot plate until the tissue adhered to the slide. Slides 
were placed in an auto stainer which rehydrated the tissue, stained with hematoxylin and eosin, then dehydrated in ethanol and xylene. A coverslip was then affixed.

Larvae were collected from spawning colonies in the laboratory for investigations of larval settlement and post-larval development. In the settlement experiments, a total of 96 larvae were placed into 4 replicates of 4 treatments, 6 larvae in each replicate. The 4 substrate treatments were hexactinellid sponge, shale, granite, and glass (control). Initially, approximately $50 \%$ of the total water volume was changed daily in the dishes. After two weeks, a $0.5 \mathrm{~mm}$ mesh plastic screen was placed over the dishes and a trickle distribution seawater system installed. Observations of settlement and metamorphosis processes were recorded daily for 2 weeks, then twice a week for an additional 2 months. Once metamorphosed polyps were noted, they were fed homogenized krill twice a week. After 2 months, the remaining viable larvae were placed in a large dish containing the various substrata to determine the length of competency. Recently settled larvae which became detached were monitored to determine their capacity for reattachment.

Settlement data were analyzed with a randomization test using the program 'Resampling Statistics.' The data were pooled, then drawn randomly and placed into four categories corresponding the substrate treatments in the experiment. One thousand iterations were used to determine the probability of similar settlement results occurring by chance alone. To further examine the causative factors suggested by the first settlement experiment, additional substrate treatments were added. Granite substrate collected at depth was placed in 2 dishes. One dish was left in running seawater for 1 
month, while the other was left dry. Six larvae were placed into each dish and observed for 3 weeks.

Growth measurements of adult colonies included stalk diameter, maximum capitulum diameter, and number of autozooids. Stalk diameter was measured at the narrowest point, corresponding to a slight change in color of the tissue. Data collected on post-larval and juvenile colonies included development stage, minimum diameter, and number of autozooids. Data were obtained 3 times a week, with average weekly values used in the subsequent analysis. Stalk diameter was plotted against capitulum diameter and number of autozooids to determine if there was a significant relationship between the various size parameters measured.

Growth rates of individual colonies did not provide sufficient data to fit to a growth model, therefore data from several individuals were combined (Fig. 6). Juvenile colonies of known ages were plotted first. Growth data from additional colonies were then fitted to the figure such that their size at initial measurement corresponded to the end point of growth measurements from another colony. The result was a chart of sizespecific growth rate for a period of over 4 years. A Gompertz growth model was fitted to this composite data using the method provided by Ricker (1979). This involved plotting a conversion factor based on proportion of asymptotic size against age. The best-fit line for these data was used to determine the parameters of the growth model. Two types of confidence intervals were calculated for the growth curves. First, measurement error was calculated as the standard error of the 3 stalk diameter measurements taken within a 
week. Growth rate variability was determined from variability in size at age. Second, maximum and minimum stalk diameter measurements for colonies of a given age were plotted, and additional Gompertz functions fitted to these data.

\section{Results}

Gonadal development

All reproductive structures of Anthomastus ritteri were found in the siphonozooids of the colony. All of the colonies examined were gonochoristic. Female gonads (oocytes) tended to be yellowish in color, while the male gonads (spermaries) were white. The early stages of gonad development occurred on the mesenteries (Fig. 2a, 3a). As the gonads matured, they began to fill the gastrovascular cavity of the siphonozooids. Histological sections revealed four stages of gonad development in both males and females. Individual zooids were observed to contain gonads in all 4 stages.

In females, stage I oocytes were found embedded in the mesenteries, and measured $24.5 \mu \mathrm{m}(\mathrm{sd}=5.6 \mu \mathrm{m}, \mathrm{n}=17)$ in diameter (Table 1) (Fig. 2a). Stage II oocytes increased in diameter to $54.0 \mu \mathrm{m}(\mathrm{sd}=12.6 \mu \mathrm{m}, \mathrm{n}=8)$, and were still connected to the mesenteries by a short pedicel (Fig. 2b). Stage III oocytes were occasionally connected to the mesenteries and measured $110.5 \mu \mathrm{m}(\mathrm{sd}=42.4 \mu \mathrm{m}, \mathrm{n}=13$ ) (Fig. 2b). Vitellogenesis began in stage III oocytes. Stage IV oocytes $(376.0 \pm 178.8 \mu \mathrm{m}, \mathrm{n}=4)$ were mature and filled with yolk droplets which stained a conspicuous pink color (Fig. 
2c). Development of oocytes through the four stages involved a continuous increase in ooplasm as well as a thickening of the follicular layer in the latter stages.

Spermaries in stage I $(21.5 \pm 6.7 \mu \mathrm{m}, \mathrm{n}=27$, Table 1$)$ were composed of spermatogonia embedded in the mesenteries of the siphonozooids (Fig. 3a). In stage II spermaries, spermatocytes formed from the spermatogonia. Spermaries in this stage remained attached to the mesenteries and measured $54.6 \mu \mathrm{m}(\mathrm{sd}=23.0 \mu \mathrm{m}, \mathrm{n}=28)$ in diameter (Fig. 3b). Spermatocytes divided and gave rise to immature spermatids in stage III. Spermatids were arranged along the interior of the spermary with their tails pointed towards the center (Fig. 3c). Spermaries in stage III measured $133.8 \mu \mathrm{m}$ (sd $=53.4 \mu \mathrm{m}$, $\mathrm{n}=20$ ) in diameter. Spermatids grew into mature spermatozoa in stage IV spermaries $(170.3 \pm 42.3 \mu \mathrm{m}, \mathrm{n}=12)$ (Fig. 3d). As stage IV spermaries developed, they filled with spermatozoa until bursting to release mature sperm cells.

Fertilization occurred internally in the siphonozooids of female colonies. Developing embryos and larvae were brooded in the gastrovascular cavity of the siphonozooids until mature. A. ritteri planulae were large $(3.3 \pm 1.0 \mathrm{~mm}$ length, $0.9 \pm 0.1$ $\mathrm{mm}$ width, $\mathrm{n}=18$ ) (Fig. 2d). Larvae were released through the oral opening of the siphonozooids at the capitulum surface. Planulae crawled by ciliary action or were passively transported until settlement. Planulae were lecithotrophic and typically settled within 2 to 3 days, although settlement and metamorphosis in some was delayed up to 4 months in the laboratory. 
A typical $A$. ritteri colony contained an average of 136 siphonozooids per $\mathrm{cm}^{2}$ of surface area ( $(\mathrm{sd}=38.3, \mathrm{n}=8)$. An average of $14 \%$ of these siphonozooids contained gonads in some stage of development $(\mathrm{sd}=2.4 \%, \mathrm{n}=8)$. A single female siphonozooid contained an average of 5.3 oocytes $(s d=2.7, n=8)$. Numbers of oocytes appeared to decrease as they matured. Based on these results, a large adult colony with a capitulum diameter of over $100 \mathrm{~mm}$ could contain in excess of 10,000 oocytes at different stages of development at any one time.

Larval settlement and development

During the course of the study, 8 different $A$. ritteri colonies underwent spawning events in the laboratory. A total of 141 planula larvae were collected from spawning colonies. Out of the 6 larvae placed into each of the replicates, an average of $4.75 \pm$ 0.229 settled on the sponge substrate, $2.75 \pm 0.698$ settled on the shale treatment, and none settled on the other two treatments; granite and control (Table 2). The probability of obtaining similar results (i.e. no settlement in 2 of the treatments) by chance alone is less than $0.8 \%$, as determined by the randomization test. In the additional granite treatments, 3 larvae settled in the dish with an organic film. No settlement had occurred after 3 weeks in the dish which had been dry prior to the introduction of larvae.

A summary of post-larval development times is presented in Table 3. Planulae initially attached to the substrate $2-3$ days after spawning. The last competent larvae settled after 123 days, approximately 4 months after larvae were released. Initial 
attachment of larvae involved adhesion to the substrate by mucous. If removed, larvae were capable of re-settlement at this stage. Larvae entered the Edwardsia stage with the formation of eight primary mesenteries approximately 2 days after settlement. Two to 3 days later the larvae metamorphosed. This involved the formation of eight tentacle buds and permanent attachment to the substrate. A basal layer of double capstan spicules was formed enclosing small particles of substrate. If primary polyps were removed at this stage they reattached to the substrate only if portions of this basal layer remained intact. Within a week after permanent attachment, the tentacles became pinnate. This marked the onset of feeding. A second autozooid began to form opposite the siphonoglyph of the primary polyp 6 to 8 weeks after feeding began. The production of additional autozooids in the colony progressed slowly and was highly variable. The third and fourth autozooids appeared almost simultaneously on either side of the second, opposite the siphonoglyph. At this point, approximately 8 - 10 months after settlement, the onset of capitulum development occurred with an increase in coenenchyme volume. The stalk diameter near the base of the primary polyp began to increase more rapidly after this stage.

Colony growth

The diameter of the stalk exhibited the smallest day to day variability and was therefore used as the basis of the growth investigations. There was a highly significant linear relationship between stalk diameter and the other morphological parameters measured (capitulum diameter $r^{2}=0.903$, number of autozooids $r^{2}=0.937$, Fig.4). 
The sizes of 30 juvenile colonies from the settlement experiments and 17 adult colonies collected by submersible were measured from April 1997 through August 1998. Twenty-two juvenile colonies and 4 adults died during this time. Many colonies exhibited short periods of negative growth in the laboratory (Fig. $5 \mathrm{a}-\mathrm{d}$ ). Growth data from 15 small colonies were combined to produce an approximate indicator of size at age through the first 50 months (Fig. 6). These data indicated slow initial growth followed by an exponential increase in stalk diameter approximately two years after settlement. Larger adults did not show a significant change in size during the course of the study (Fig. 5 d).

A Gompertz growth function was fitted to these data. The best fit for the points generated from the conversion factors (Fig. 7) provided the parameters for the curve (Ricker 1979). The Gompertz function follows the formula $l=L e^{-e g\left(t-t_{0}\right)}$ where $l=$ stalk diameter, $\mathrm{L}=$ asymptotic stalk diameter, $\mathrm{g}=$ instantaneous rate of growth when $\mathrm{t}=\mathrm{t}_{\mathrm{o}}$, and $t_{0}=$ time at the inflection point. The curve is shown in figure $8 \mathrm{a}$ and $\mathrm{b}$ has the following parameters: $\mathrm{L}=102, \mathrm{~g}=0.0145, \mathrm{t}_{\mathrm{o}}=103.0$. The error shown in $8 \mathrm{a}$ represents variability in growth rate as expressed by additional Gompertz functions with the following parameters: positive error (rapid growth) $\mathrm{L}=103, \mathrm{~g}=0.0150, \mathrm{t}_{\mathrm{o}}=99.5$; negative error (slow growth) $\mathrm{L}=99, \mathrm{~g}=0.0139, \mathrm{t}_{\mathrm{o}}=108.2$. The error in $8 \mathrm{~b}$ is based on measurement error $(s e=0.061)$. 


\section{Discussion}

\section{Gonadal Development}

While the mode of reproduction is highly variable within the order, Anthomastus ritteri shared certain features with many tropical alcyonacean species. Shared strategies included internal brooding to a planula larvae, internal fertilization, and gonochorism (Benayahu and others 1989, Williams 1990, Benayahu 1991). In general, these features are more common in temperate and deep-sea invertebrates (Gage and Tyler 1991, Coma and others 1995a). Deep-sea zoanthids are usually dioecious, continually reproductive, and produce planktotrophic larvae (Muirhead and others 1986). Seasonal reproduction has been reported for a few deep-sea actiniarians, coordinated with the deposition of organic products from the spring phytoplankton bloom (van Praet 1990, van Praet and others 1990). A. ritteri colonies did not exhibit a seasonal reproductive pattern in the laboratory.

The development of gonads in $A$. ritteri closely resembled that of another alcyonacean, Anthelia glauca (Kruger and others 1998). A. glauca is a coral reef xeniid which broods planulae in intersiphonozooid spaces on the surface of the capitulum. While the gonads appeared on the mesenteries of the siphonozooids in $A$. ritteri, $A$. glauca colonies are monomorphic and gonad development occurs seasonally in the autozooids. Despite these differences, spermary and oocyte development in both species proceeds through the same four distinct stages. The site of gonad development may differ, but the pattern of development remained unchanged. 
During oocyte development in $A$. ritteri, the number of female gonads within a zooid decreased. This suggests that material is resorbed within the zooid, although this process was not directly observed in $A$. ritteri. Resorbtion of oocytes has been reported for tropical scleractinians (Rinkevich and Loya 1979a) and temperate alcyonaceans (Farrant 1986). In most deep-sea invertebrates, unfertilized oocytes will be resorbed (Gage and Tyler 1991). Like many other deep-sea species, A. ritteri lacked synchrony in the production of gametes within a breeding population. Resorbtion of oocytes may be a mechanism for reducing the energy requirement of continuous production of gametes.

Bursting of mature spermaries to release sperm has been observed in other alcyonaceans (Benayahu and Loya 1984a; 1984b). This is believed to be the mechanism of release in $A$. ritteri, though sperm release was never observed in live colonies. Mature stage IV spermaries were observed with ruptures in the spermary membrane. This suggests that stage IV spermaries burst within a zooid to release relatively small numbers of sperm, although the ruptures may have been an artifact of tissue processing during histological preparations. However, if mature spermaries were released intact, this event would most likely have been observed during the course of the study.

Larval settlement and development

Settlement and metamorphosis appeared to be induced by the presence of an organic film. The only factor in the original design of the settlement experiment was substrate type (and indirectly, the heterogeneity of the substrate). However, 2 of the 
substrate treatments, granite and glass, were not placed in running seawater for any length of time prior to the introduction of larvae. Therefore, there was no opportunity for a organic film to become established. No settlement was observed on these treatments. Presence of a film was added as a variable post-hoc. The low probability of randomly obtaining similar results $(\mathrm{p}<0.008)$ suggests that larvae of $A$. ritteri will not settle and metamorphose in the absence of an organic film.

Additional settlement dishes were added to further examine the effects of organic films on settlement. Due to the paucity of spawning colonies in the laboratory, these additional treatments could not be replicated. While they could not be tested statistically, these results supported the conclusions drawn from the initial experiment. The lack of settlement on the substrates without an organic film further suggested induction of settlement by the presence of organic products rather than a specific substrate type. Bacterial films and other surface organics are some of the most commonly reported settlement cues for cnidarians in the literature (Brewer 1976a; 1976b for scyphozoa; Muller and others 1976 for hydroids; Richmond 1985, Shlesinger and Loya 1991, McGuire 1995 for scleractinians). Bacterial products have even been shown to induce metamorphosis of cnidarian larvae in suspension without substrate (Chia and Bickell 1977). The hypothesis that metamorphosis was induced by organic film in $A$. ritteri was further supported by the observation of $A$. ritteri colonies on all of the substrate types tested. Juvenile $A$. ritteri were also noted on the holothurian Psolus sp. at 
the time of collection, as well as on glass and plastic surfaces in the seawater system in the laboratory.

Initial settlement of larvae involves attachment to substrate by mucous secreted by gland cells, and possibly by the use of nematocysts (Chia and Crawford 1973, Muller and others 1976, Chia and Bickell 1977). While attachment by nematocysts has been observed in other species, this was not observed in $A$. ritteri. After initial attachment, larvae may be removed and re-settle. Detachment has been suggested to be a method of "bottom sampling" to search for an appropriate habitat for metamorphosis (Jackson 1986). This behavior may also increase a species' dispersion potential (Richmond 1985). In certain scleractinian species, reversion from a fully metamorphosed polyp inside a calyx to a larval form has been noted (Richmond 1985). A. ritteri does not appear to be capable of this type of reversion. Once the basal layer of sclerites has been laid down on the substrate, portions of this layer must be included in a detached polyp for it to settle in another location.

Internal fertilization and brooding of developing embryos coupled with a short lived, lecithotrophic, crawling planula are thought to be mechanisms for assuring colonization of suitable substrate (Ostarello 1976, Gerrodette 1981, Sebens 1983b, Fautin and Sebens 1987). Settlement of cnidarian planulae usually occurs within $1-4$ days (Otto 1976, Gerodette 1981, Richmond 1985, Farrant 1986, Benayahu and Loya 1987, Fautin and Sebens 1987, McGuire 1995, Ben-David-Zaslow and Benayahu 1998). $A$. ritteri larvae were competent to settle 2 days after spawning. Short pre-competency 
periods will effectively limit the distance traveled before settlement (Pechenik 1990). By localizing dispersal, maintenance of existing populations may be achieved without the high degree of larval mortality associated with the planktonic mode of development (Sebens 1983a, Coma and others 1995a).

Reduced dispersal distances are common in temperate coral species (Coma and others 1995a). Because the environment tends to be more variable both spatially and temporally, localized dispersal in temperate regions will increase the chance of encountering appropriate conditions for post-larval development and survivorship. Local dispersal benefits $A$. ritteri in Monterey Bay where temporally variable current flow, particularly in the submarine canyon, may transport planktonic larvae away from suitable habitat. Bottom currents in the canyon can reach velocities of $1 \mathrm{~m} / \mathrm{sec}$ or more for a height of up to $15 \mathrm{~m}$ above the bottom (Breaker and Broenkow 1994). These vigorous currents normally flow up-canyon, although the direction and speed of flow is very irregular (Breaker and Broenkow 1994).

High current flow coupled with longevity of larvae can transport demersal larvae well away from local populations (Gerrodette 1981, Sebens 1983a, Farrant 1986, Pechenik 1990, McFadden 1991). Larvae may travel great distances even if immediately competent (Pechenik 1990). Maximum dispersal potential for larvae is mainly determined by the length of time between larval release and metamorphosis (Pechenik 1990, Ben-David-Zaslow and Benayahu 1998). The duration of the larval competency period is directly related to the energetic content of larvae (Ben-David-Zaslow and 
Benayahu 1998). The energy available to lecithotrophic larvae increases with large size and high lipid content (Rice and others 1992, Kruger and others 1998). The long competency period recorded for $A$. ritteri larvae is therefore related to their large size. $A$. ritteri planula larvae are among some of the largest alcyonacean larvae recorded.

Planulae are normally $1.5-2 \mathrm{~mm}$ in length, with the largest recorded alcyonacean larvae between 3.5 and $4 \mathrm{~mm}$ (Benayahu and others 1989). The larvae examined in this study had an average length of $3.3 \mathrm{~mm}$ and a width of $0.9 \mathrm{~mm}$.

A competency period of up to 4 months, as suggested by laboratory observations, is not uncommon among cnidarian larvae. Scleractinian larvae may remain competent for 6 to 7 months (Connell 1973, Lewis 1974, Richmond 1985), while the planulae of Alcyonium siderium settled after 9 months in the laboratory (Sebens 1983a). Maximal competence periods of 74 and 76 days were measured for the alcyonaceans Dendronephthya hemprichi and Xenia umbellata respectively (Ben-David-Zaslow and Benayahu 1998).

The models which have been proposed to explain the advantage of delayed metamorphosis made two predictions (Pechenik 1990). 1. That potential for delay is correlated with the length of the pre-competence period and 2. the extent of the delay should reflect the amount of difficulty in selecting suitable habitat. These hypotheses do not explain the evolution of this mechanism in $A$. ritteri since planulae are competent within 2 days, and habitat is available almost immediately after release in situ. Long 
range dispersal may benefit $A$. ritteri by increasing the degree of genetic exchange between populations (Strathmann 1974).

Another advantage to long range dispersal may be the establishment of populations in previously uncolonized habitat. The probability of this occurrence may be enhanced by gregarious settlement. This is common among anthozoan planulae, though not tested for $A$. ritteri (Lewis 1974, Ostarello 1976, Gerodette 1981, Sebens 1983b). Newly established $A$. ritteri populations would only be maintained if multiple larvae settled in close proximity to one another due to the limited dispersal range of male gametes.

The maintenance of large numbers of developing embryos and larvae within a single colony with sporadic spawning of groups of larvae may provide a mechanism for A. ritteri to take advantage of both long and short range dispersal. Within a population, colonies will release larvae at different times under a variety of environmental conditions. Larvae will encounter temporal variability in flow regime and current velocity. During periods of high speed flow in the canyon, larvae will be transported away from existing populations. When current flow is reduced, planulae may simply crawl to a nearby patch of open space. This will ensure the persistence of established populations while providing a mechanism for the colonization of new habitat. 
Growth

A variety of morphological and behavioral features increased the variability in growth measurements. The colonies are able to bend the stalk slightly, and are able to contract the capitulum diameter by controlling the water flow through the siphonozooids. While number of autozooids in the colony was easily measured and showed little variability, this is not a continuous variable and therefore not an appropriate measure, particularly for small colonies. The high degree of correlation between stalk diameter and the other parameters measured $(>90 \%)$ provided a certain level of confidence in its use. Growth rates of shallow water $(<27 \mathrm{~m})$ gorgonian corals have been determined from a variety of measurements including total height (Velimirov 1975) branching pattern (Velimirov 1975, Kim 1995), growth rings (Grigg 1974, Mitchell and others 1993), and basal diameter (Mistri 1995). Mistri (1995) examined the relationships between basal diameter and a number of morphometric traits including height, effective area, total branch length, and rectangular area and found significant regression indices. She determined that basal diameter was the best parameter for describing the growth of the gorgonian examined. She used these data to formulate a von Bertalanffy growth function. In his description of the growth pattern of the gorgonian Eunicella cavolinii, Velimirov (1975) used a sigmoidal function similar to the Gompertz function used here. Growth models are chosen based on their goodness of fit to size data and convenience (Ricker 1979). The observed growth pattern of $A$. ritteri most closely fits the Gompertz growth model. This curve describes slow initial growth, followed by a 
period of relatively rapid growth at intermediate size, eventually reaching an asymptotic limit. This describes the growth of $A$. ritteri more closely than the frequently used Bertalanffy growth model.

There appears to be a physiological justification for the use of the Gompertz model based on the dependence of feeding rate on effective surface area (Sebens 1979). In the juvenile stage (1-4 autozooids), A. ritteri colonies exhibit very slow growth rates. The surface area of polyp tentacles available for food capture is very small in this stage. Energy acquired may not manifest itself in quantifiable growth. Instead, it is probably reallocated to formation of the solenia network and the first siphonozooids.

Siphonozooids are not necessary to transport nutrients between zooids until the colony reaches a certain volume with the expansion of the coenenchyme and formation of the capitulum.

Once the capitulum is formed, the colony begins to grow rapidly. At this stage, the anthocodia are distributed around the surface of the capitulum such that there is little interference between them. This results in a high particle capture rate per polyp (McFadden 1986). A larger surface area available for feeding increases the energy available for growth.

When a colony reaches a certain size, growth slows. In fully grown colonies, appreciable growth was not observed over the course of 18 months. Observed changes in size were well within the measurement error. Negligible growth rates could be attributed to interference by neighboring polyps within a colony. In a study of another alcyonacean, 
McFadden (1991) suggested that above a certain colony size, the per polyp capture rate of particles will decrease due to an overlap of feeding polyp tentacles. Autozooids will actually begin to compete with one another for food particles. This will decrease the relative amount of resources available to an individual polyp within the colony. This competition for resources was shown to slow the overall growth of the colony. The alcyonacean in the McFadden (1991) study was able to overcome this deficiency through colony fission, which does not occur in $A$. ritteri. This suggests a physiological basis for the high rate of growth at intermediate size and reduced growth rates of adults recorded for $A$. ritteri.

The data used to create the growth model were based on a size specific growth rate. Age estimates derived from size dependent growth rates have been shown to be reliable for gorgonians (Grigg 1977). Ideally, individual colonies should be traced over their entire life spans, or size frequency data from multiple surveys should be used as a basis for a growth model (Ebert 1973). The acquisition of these data is difficult and expensive for a slow growing deep-sea sessile organism. It is believed that the method devised here is reliable assuming that there is little variability in size at age for juvenile and intermediate sized colonies. This appeared to be the case for the colonies examined in the laboratory.

An underlying assumption of the growth model is that there is a consistent size limit for $A$. ritteri. The colonies examined in this study appeared to have very different asymptotic sizes. The data used as a basis for the curve suggested an asymptote around 
$102 \mathrm{~mm}$. However, smaller colonies with a stalk diameter of approximately $60 \mathrm{~mm}$ appeared to have reached their maximum size. The largest $A$. ritteri recorded had a stalk diameter of $87.9 \mathrm{~mm}$. Individual variability in growth rate can lead to serious overestimates of length at age when growth increment data are used to formulate growth models (Sainsbury 1980). The discrepancy between the asymptotic sizes measured and that suggested by the model may also be an artifact of the method of deriving the Gompertz parameters. The model was based on data from juvenile colonies and small sized adults. Large colonies were not included because the data were not continuous and they could not be fit to the curve. Consequently, the model shown in Figure 8 contains sections of the curve plotted well beyond the range of data from which it was calculated. This fact, in conjunction with the high degree of error at the right end of the model, prevents a precise determination of age for large colonies. For example, a colony with a stalk diameter of $88 \mathrm{~mm}$ could be anywhere from 18 to 24 years of age.

Another confounding factor in the growth model is that the conditions of the laboratory where growth was measured deviated from the conditions in situ. While laboratory temperatures approximated those of the natural environment, pressure levels as well as dissolved oxygen content did not. Much of the A. ritteri population in Monterey Bay lives well within the oxygen minimum zone at pressures above 100 ATM. In addition, food availability would differ in situ. Laboratory conditions could alter growth rates, lending a degree of uncertainty to the results of the model (Farrant 1986). 
However, because so few studies of growth rates of alcyonaceans and deep-sea cnidarians exist, this laboratory study serves as a useful basis for future investigations.

Growth rates of corals are highly determined by environmental factors. The most significant physical factor affecting coral growth is mechanical damage incurred from sedimentation and abrasion (Grigg 1977, Gotelli 1988, Reigl 1995, Ward 1995). Flow rate and small scale hydrodynamic processes may also influence growth by determining particle capture rates of suspension feeding colonies (Velimirov 1975, McFadden 1986, Fabricius and others 1995). While the majority of these factors would not affect $A$. ritteri colonies grown in the laboratory, environmental conditions may have determined the asymptotic size of certain colonies before their capture.

Biological factors such as partial predation have also been shown to alter growth rates in situ. Predation as well as mechanical damage act by influencing the allocation of energy to growth, repair, defense, and reproduction (Bayer 1973, Grigg 1974, Hughes and Jackson 1980, Hughes 1984, Harvell and Suchanek 1987, Mistri 1995). A. ritteri colonies were not exposed to potential predators in the laboratory, although ciliate infection may slow growth. When a small wound was inflicted on a colony, it became rapidly infected with ciliates from the seawater system of the laboratory. As a defense, damaged colonies produced large amounts of enlarged rod-like spicules in the affected area, similar to certain gorgonian species (Bayer 1973, Harvell and Suchanek 1987). The formation of these enlarged spicule networks would reduce the energy available for growth. Advanced infections led to rapid deterioration of colonies in the laboratory. 
Mortality of juvenile and adult colonies during the growth study was attributed to ciliate infection.

While a number of factors may affect the accuracy of the growth model, certain parameters of the model approximate others reported for octocorals. Asymptotic size was reached after 15 years in the gorgonian Eunicella cavolinii in the Mediterranean (Velimirov 1975). Another Mediterranean gorgonian, Paramuricea clavata, had not reached its maximum size at 15 years of age (Mistri 1995). The asymptote suggested by the growth model for $A$. ritteri complies with the general notion that growth rates are reduced and longevity increased in deep-sea organisms (Gage and Tyler 1991, Coma and others $1995 \mathrm{~b}$ ).

\section{Conclusions}

The mode of reproduction of Anthomastus ritteri, including continual reproduction, larval brooding, and lecithotrophic larvae are common features of temperate and deep-sea cnidarians. These are also widely employed strategies in alcyonaceans in general. Larval brooding coupled with demersal larvae provide a mechanism for the conservation of local populations. Long range dispersal of larvae may be provided by current transport and the relative longevity of the larvae. Larvae appear to settle on any available substrate covered by an organic film, similar to most cnidarians investigated. Once metamorphosed, growth is slow initially. Growth of colonies is rapid at intermediate sizes, slowing in adults to an asymptote at approximately 25 to 30 years. 
This growth pattern may be explained by changes in the particle capture rate per polyp with increasing size.

While there are a number of potential sources of error in the growth model, it serves as a general approximation of growth for $A$. ritteri. The importance of this model lies in the fact that this is one of the only quantitative studies of growth rates in cnidarians, and deep-sea invertebrates as a whole. The reliability of the model may be tested with future measurements of growth in situ. A number of experimental manipulations are required to examine the relative effects of different environmental variables on $A$. ritteri growth rates. 


\section{LITERATURE CITED}

Alino P.M., Coll J.C. 1989. Observations of the synchronized mass spawning and postsettlement activity of octocorals on the Great Barrier Reef, Australia: Biological aspects. Bull Mar. Sci. 45: 697-707.

Bayer F.M. 1973. Colonial organization in octocorals. In: R.S. Boardman, A.H. Cheetham, W.A. Oliver eds. Animal Colonies: Development and Function Through Time. Dowden Hutchinson and Ross Inc. Stroudsburg PA. 69-93.

Ben-David-Zaslow R., Benayahu Y. 1996. Longevity, competence, and energetic content in the planulae of the soft coral Heteroxenia fuscescens. J. Exp. Mar. Biol. Ecol. 206: 55-68.

Ben-David-Zaslow R., Benayahu Y. 1998. Competence and longevity in planulae of several species of soft corals. Mar. Ecol. Prog. Ser. 163: 235-243.

Benayahu Y. 1991. Reproduction and developmental pathways of Red Sea Xeniidae (Octocorallia, Alcyonacea). Hydrobiologia 216/217: 125-130.

Benayahu Y. 1995. Species composition of soft corals (Octocorallia, Alcyonacea) on the coral reefs of Sesoko Island, Ryukyu Archipelago, Japan. Galaxea 12: 103-124.

Benayahu Y., Berner T., Achituv Y. 1989. Development of planulae within a mesogleal coat in the soft coral Heteroxenia fuscesens. Marine Biology 100: 203-210.

Benayahu Y., Loya Y. 1984a. Life history studies on the Red Sea soft coral Xenia macrospiculata Gohar, 1940. I. Annual dynamics of gonadal development. Biological Bulletin 166: 32-43.

Benayahu Y., Loya Y. 1984b. Life history studies on the Red Sea soft coral Xenia macrospiculata Gohar, 1940. II. Planulae shedding and post larval development. Biological Bulletin 166: 44-53.

Benayahu Y., Loya Y. 1987. Long-term recruitment of soft-corals (Octocorallia: Alcyonacea) on artificial substrata at Eilat (Red Sea). Marine Ecology Progress Series 38: 161-167.

Benayahu Y., Schleyer M.H. 1998. Reproduction in Anthelia glauca (Octocorallia: Xeniidae). II. Transmission of algal symbionts during planular brooding. Marine Biology 131:433442.

Breaker L.C., Broenkow W.W. 1994. The circulation of Monterey Bay and related processes. Oceanogr. Mar. biol. 32: 1-64.

Brewer R.H. 1976a. Larval settling behavior in Cyanea capillata (Cnidaria: Scyphozoa). Biological Bulletin 150: 183-199.

Brewer R.H. 1976b. Some microenvironmental influences on attachment behavior of the planula of Cyanea capillata (Cnidaria: Scyphozoa). In: G.O. Mackie, ed. Coelenterate Ecology and Behavior. Plenum Publishing Corp. New York. 347-354. 
Brewer R.H. 1984. The influence of orientation, roughness, and wettability of solid surfaces on the behavior and attachment of planulae of Cyanea (Cnidaria: Scyphozoa). Biological Bulletin 166: 11-21.

Brusca R.C., Brusca G.J. 1990. Invertebrates. Sinauer Associates Inc. Sunderland MA. 922pp.

Campbell R.D. 1974. Chapter IV: Development. In: L. Muscatine, H.M. Lenhoff eds. Coelenterate Biology: Reviews and New Perspectives. Academic Press. New York.179210.

Chandrasekaran R. 1991. Endogenous thythms in the soft coral Anthomastus ritteri. Unpublished manuscript from Hopkins Marine Station. 12pp.

Chia F.S., Bickell L.R. 1977. Mechanisms of larval attachment and the induction of settlement and metamorphosis in coelenterates: a review. In: F.S. Chia, M.E. Rice. Settlement and Metamorphosis of Marine Invertebrate Larvae. 1-12.

Chia F.S., Crawford B.J. 1973. Some observations on gametogenesis, larval development, and substratum selection of the sea pen Ptilosarcus guerneyi. Marine Biology 23: 73-82.

Childress J.J., Price M.H. 1978. Growth rate of the bathypelagic crustacean Gnathophausia ingens (Mysidacea: Lophogastridae) I. dimensional growth and population structure. Marine Biology 50: 47-62.

Coma R., Ribes M., Zabala M., Gili J.M. 1995a. Reproduction and cycle of gonadal development in the Mediterranean gorgonian Paramuricea clavata. Marine Ecology Progress Series 117: 173-183.

Coma R., M. Ribes, M. Zabala, J.M. Gili. 1995b. Growth and reproduction in a modular marine invertebrate. In: J.P. Grassle, A. Kelsey, E. Oates, P.V. Snelgrove, eds. Twenty-third Benthic Ecology Meeting. New Brunswick NJ.

Connell J. 1973. Population ecology of reef building coral. In: O.A. Jones, R. Endean eds. Biology and Geology of Coral Reefs. Vol.II Biology. Academic Press, New York. 205245.

Dahan M., Benayahu Y. 1998. Embryogenesis, planulae longevity, and competence in the octocoral Dendronephthya hemprichi. Invert. Biol. 117:271-280.

d'Hondt M.J. 1988. Anthomastus tahinodus n. sp., Octocoralliare Alcyonacea du nord-est de Tahiti. Bulletin of the National Museum of Natural History, Paris 10: 265-276.

d'Hondt M.J. 1992. Description d'Anthomastus globosus n. sp. (Octocorallia, Alcyonacea) de Nouvelle-Caledonie Remarques sur quelques especes du genre. Bulletin of the National Museum of Natural History, Paris 14: 623-638.

Ebert T.A. 1973. Estimating growth and mortality rates from size data. Ocecologia (Berlin) 11: 281-298. 
Fabricius K.E., Genin A., Benayahu Y. 1995. Flow-dependent herbivory and growth in zooxanthellae-free soft corals. Liminol. Oceanogr. 40: 1290-1301.

Farrant P.A. 1986. Gonad development and the planulae of the temperate Australian soft coral Capnella gaboensis. Marine Biology 92: 381-392.

Fautin D.G., Sebens K.P. 1987. Chapter 4. Phylum Cnidaria, Class Anthozoa. In: M.F. Strathmann ed. Reproduction and Development of Marine Invertebrates of the North Pacific Coast: Data and methods for the study of eggs, embroys, and larvae. University of Washington Press, Seattle. 83-104.

Gage J.D. 1987. Growth of the deep-sea irregular sea urchins Echinosigra phiale and Hemiaster expergitus in the Rockall Trough (N.E. Atlantic Ocean). Marine Biology 96: 19-30.

Gage J.D. 1990. Skeletal growth markers in the deep-sea brittle stars Ophiura jungmani and Ophiomusium lymani. Marine Biology 104: 427-435.

Gage J.D., Tyler P.A. 1985. Growth and recruitment of the deep-sea urchin Echinus affinis. Marine Biology 90: 41-53.

Gage J.D., Tyler P.A. 1991. Deep-Sea Biology: A natural history of organisms at the deep-sea floor. Cambridge University Press, Cambridge. 504 pp.

Gerrodette T. 1981. Dispersal of the solitary coral Balanophyllia elegans by demersal planular larvae. Ecology 62: 611-619.

Gilkinson K.D., Hutchings J.A., Oshell P.E., Haedrich R.L.. 1986. Shell microstructure and observations on internal banding patterns in the bivalves Yolida thraciaeformis Storer, 1838, and Nuculana permula Muller, 1779 (Nuculanidae), from a deep-sea environment. Veliger 29: 70-77.

Gotelli N.J. 1988. Determinants of recruitment, juvenile growth, and spatial distribution of a shallow water gorgonian. Ecology 69: 157-166.

Grigg R.W. 1974. Growth rings: annual periodicity in two gorgonian corals. Ecology 55: 876881 .

Grigg R.W. 1977. Population dynamics of two gorgonian corals. Ecology 58: 278-290.

Hartnoll R.G. 1977. Reproductive strategy in two British species of Alcyonium. In: B.F. Keegan, P.O. Ceidigh, P.J.S. Boaden, eds. Biology of Benthic Organisms. $11^{\text {th }}$ European Symposium on Marine Biology. Gateway UK.

Harvell C.D., Suchanek T.H.. 1987. Partial predation on tropical gorgonians by Cyphoma gibbosum (Gastropoda). Marine Ecology Progress Series 38: 37-44.

Hughes T.P. 1984. Population dunamics based on individual size rather than age: a general model with a reef coral example. The American Naturalist 123: 778-795. 
Hughes T.P., Jackson J.B.C.. 1980. Do corals lie about their age? Some demographic consequences of partial mortality, fission and fusion. Science 209: 713-715.

Hutchings J.A., Haedrich R.L. 1984. Growth and population structure in two species of bivalves (Nuculanidae) from the deep-sea floor. Marine Ecology Progress Series 17: 135-142.

Jackson G.A. 1986. Interaction of physical and biological processes in the settlement of planktonic larvae. Bulletin of Marine Science 39: 202-212.

Jungersen H.F.E. 1927. Anthomastus. In: The Danish Ingolf-Expedition Vol. V No. II. Bianco Luno. Copenhagen. 14pp.

Kim K. 1995. Patterns of growth in gorgonian corals: A metapopulation analysis. In: J.P. Grassle, A. Kelsey, E. Oates, P.V. Snelgrove, eds. Twenty-third Benthic Ecology Meeting. New Brunswick NJ.

Kruger A., Schleyer M.H., Benayahu Y. 1998. Reproduction in Anthelia glauca (Octocorallia: Xeniidae). I. Gametogenesis and larval brooding. Marine Biology 131: 423-432.

Lampitt R.S. 1990. Directly measured rapid growth of a deep-sea barnacle. Nature 345: 805-807.

Lewis J.B. 1974. The settlement behavior of planulae larvae of the hermatypic coral Favia fragum (Esper). Journal of Experimental Marine Biology and Ecology 15: 165-172.

McFadden C.S. 1986. Colony fission increases particle capture rates of a soft coral: advantages of being a small colony. Journal of Experimental Marine Biology and Ecology 103: 120.

McFadden C.S. 1991. A comparitive demographic analysis of clonal reproduction in a temperate soft coral. Ecology 72: 1849-1866.

McGuire M. 1995. Aspects of reproduction, larval characteristics and juvenile growth in the coral Porites astreoides. In: J.P. Grassie, A. Kelsey, E. Oates, P.V. Snelgrove, eds. Twenty-third Benthic Ecology Meeting. New Brunswick NJ.

Mistri M. Gross morphometric relationships and growth in the Mediterranean gorgonian Paramuricea clavata. Boll. Zool. 62: 5-8.

Mitchell N.D., Dardeau M.R., Schroeder W.W. 1993. Colony morphology, age structure, and relative growth of two gorgonian corals, Leptogorgia hebes (Verrill) and Leptogorgia virgulata (Lamarck), from the Northern Gulf of Mexico. Coral Reefs 12: 65-70.

Muirhead A., Tyler P.A., Thurston M.H. 1986. Reproductive biology and growth of the genus Epizoanthus (Zoanthidea) from the North-East Atlantic. Journal of the Marine Biological Association of the U.K. 66: 131-143. 
Muller W.A., Wieker F., Eiben R. 1976. Larval adhesion, releasing stimuli and metamorphosis. In: G.O. Makie, ed. Coelenterate Ecology and Behavior. $3^{\text {rd }}$ International Symposium on Coelenterate Biology. Victoria B.C. 339-346.

Nutting C.C. 1909. Alcyonaria of the Californian Coast. Proceedings of the United States National Museum 35: 681-727.

Ostarello G.L. 1976. Larval dispersal in the subtidal hydrocoral Allopora californica Verrill (1866). In: G.O. Makie, ed. Coelenterate Ecology and Behavior. $3^{\text {rd }}$ International Symposium on Coelenterate Biology. Victoria B.C. $331-338$.

Otto J.J. 1976. Early development and planula movement in Haliclystus (Scyphozoa: Stauromedusae). In: G.O. Makie, ed. Coelenterate Ecology and Behavior. $3^{\text {rd }}$ International Symposium on Coelenterate Biology. Victoria B.C. 319-330.

Pechenik J.A. 1990. Delayed metamorphosis by larvae of benthic marine invertebrates: Does it occurr? Is there a price to pay? Ophelia 32: 63-94.

Rice A.L., Tyler P.A., Paterson G.J.L. 1992. The pennatulid Kophobelemnon stelliferum (Cnidaria: Octocorallia) in the Porcupine Seabight (North-East Atlantic Ocean). Jounal of the Marine Biological Association of the U.K. 72: 417-434.

Richmond R.H. 1985. Reversible metamorphosis in coral planula larvae. Marine Ecology Progress Series 22: $181-185$.

Ricker W.E. 1979. Growth rates and models. In: W.S. Hoar, D.J. Randall, J.R. Brett, eds. Fish Physiology. Vol VIII. Bioenergetics and Growth. Academic Press. New York. 677-738.

Rieg! B. 1995. Effects of sand deposition on scleractinian and alcyonacean corals. Marine Biology 121: 517-526.

Riise S.A. 1990. The distribution, feeding behavior, and anthocodia retraction of Anthomastus ritteri Nutting, 1909 in Monterey Bay. Unpublished manuscript from Hopkins Marine Station. 26pp.

Rinkevich B., Loya Y. 1979a. The reproduction of the Red Sea coral Stylophora pistillata. I. gonads and planulae. Marine Ecology Progress Series 1: 133-144.

Rinkevich B., Loya Y. 1979b. The reproduction of the Red Sea coral Stylophora pistillata. II. synchronization in breeding and seasonality of planulae shedding. Marine Ecology Progress Series 1: 145-152.

Sainsbury K.J. 1980. Effect of individual variability on the von Bertalanffy growth equation. Canadian Journal of Fisheries and Aquatic Sciences 37: 241-247.

Sammarco P.W., Coll J.C. 1992. Chemical adaptations in the Octocorallia: evolutionary considerations. Marine Ecology Progress Series 88: 93-104. 
Sebens K.P. 1979. The energetics of asexual reproduction and colony formation in benthic marine invertebrates. American Zoologist 19: 683-697.

Sebens K.P. 1983a. The larval and juvenile ecology of the temperate octocoral Alcyonium siderium verrill. I. Substratum selection by benthic larvae. Journal of Experimental Marine Biology and Ecology 71: 73-89.

Sebens K.P. 1983b. The larval and juvenile ecology of the temperate octocoral Alcyonium siderium verrill. II. Fecundity, survival, and juvenile growth. Journal of Experimental Marine Biology and Ecology 72: 263-285.

Sheltema A.H. 1987. Reproduction and rapid growth in a deep-sea aplacophoran mollusc, Prochaetoderma yongei. Marine Ecology Progress Series 37: 171-180.

Shlesinger Y., Loya Y. 1991. Larval development and survivorship in the corals Favia favus and Platygyra lamellina. Hydrobiologia 216/217: 101-108.

Strathmann R.R. 1974. The spread of sibling larvae of sedentary marine invertebrates. American Naturalist 108: 29-44.

vanPraet M. 1990. Gametogenesis and the reproductive cycle in the deep-sea anemone Paracalliactis stephensoni (Cnidaria: Actinaria). Journal of the Marine Biological Association of the U.K. 70: 163-172.

vanPraet M., Rice A.L., Thurston M.H. 1990. Reproduction in two deep-sea anemones (Actinaria); Phelliactis hertwigi and $P$. robusta. Progress in Oceanography 24: 207-222.

Velimirov B. 1975. Growth and age determination in the sea fan Eunicella cavolinii. Oecologia (Berlin) 19: 259-272.

Ward S. 1995. The effect of damage on the growth, reproduction, and storage of lipids in the scleractinian coral Pocillopora damicornis (Linnaeus). Journal of Experimental Biology and Ecology 187: 193-206.

Williams G.C. 1990. A new geuns of dimorphic soft coral from the south-western fringe of the Indo-Pacific (Octocorallia: Alcyoniidae). Journal of the Zoological Society of London 221: 21-35.

Zezina O.N. 1975. On some deep-sea brachiopods from the Gay Head - Bermuda transect. Deepsea Research 22: 903-912. 


\begin{tabular}{|c|c|c|c|}
\hline gonad stage & mean & sd & n \\
\hline o1 & 24.5 & 5.6 & 17 \\
\hline 02 & 54.0 & 12.6 & 8 \\
\hline 03 & 110.5 & 42.4 & 13 \\
\hline 04 & 376.0 & 178.8 & 4 \\
\hline & & & \\
\hline s1 & 21.5 & 6.7 & 27 \\
\hline s2 & 54.6 & 23.0 & 28 \\
\hline s3 & 133.8 & 53.4 & 20 \\
\hline$s 4$ & 170.3 & 42.3 & 12 \\
\hline
\end{tabular}

Table 1. Mean size of gonads in each of the four stages of development corresponding to the labels in figures 2 and 3 . Measurments in micrometers. 


\begin{tabular}{|r|c|c|c|c|}
\hline replicate \# & Sponge & Shale & Granite & Glass \\
\hline 1 & 3 & 5 & 0 & 0 \\
\hline 2 & 5 & 2 & 0 & 0 \\
\hline 3 & 6 & 0 & 0 & 0 \\
\hline 4 & 5 & 4 & 0 & 0 \\
\hline mean & 4.75 & 2.75 & 0 & 0 \\
\hline se & 0.229 & 0.698 & 0 & 0 \\
\hline
\end{tabular}

Table 2. Results of settlement experiment. Presented are numbers of successfully metamorphosed larvae out of 6 initially placed in each dish. 


\begin{tabular}{|c|c|c|}
\hline Larval/post larval & Size $(\mathrm{mm})$ & Time since \\
\hline development stage & sd in parentheses & spawning $(\mathrm{d}, \mathrm{m})$ \\
\hline planula & $3.3(1.0) \times 0.9(0.1)$ & $0 \mathrm{~d}$ \\
\hline initial settlement & $0.93(0.21)$ & $2-3 \mathrm{~d}^{*}$ \\
\hline edwardsia & $1.48(0.33)$ & $4-5 \mathrm{~d}$ \\
\hline permanent attachment, & & \\
\hline tentacle formation & $2.08(0.21)$ & $6-7 \mathrm{~d}$ \\
\hline tentacles pinnate & $2.21(0.17)$ & $13-14 \mathrm{~d}$ \\
\hline 2nd autozooid & $2.42(0.06)$ & $1-2 \mathrm{~m}$ \\
\hline 3rd and 4th autozooid & $3.93(0.75)$ & $8-9 \mathrm{~m}$ \\
\hline
\end{tabular}

Table 3. Anthomastus ritteri development times for larval and post-larval stages. Sizes of post-larval stages are minimum polyp diameter.

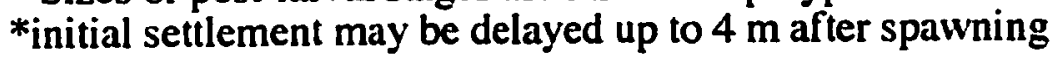




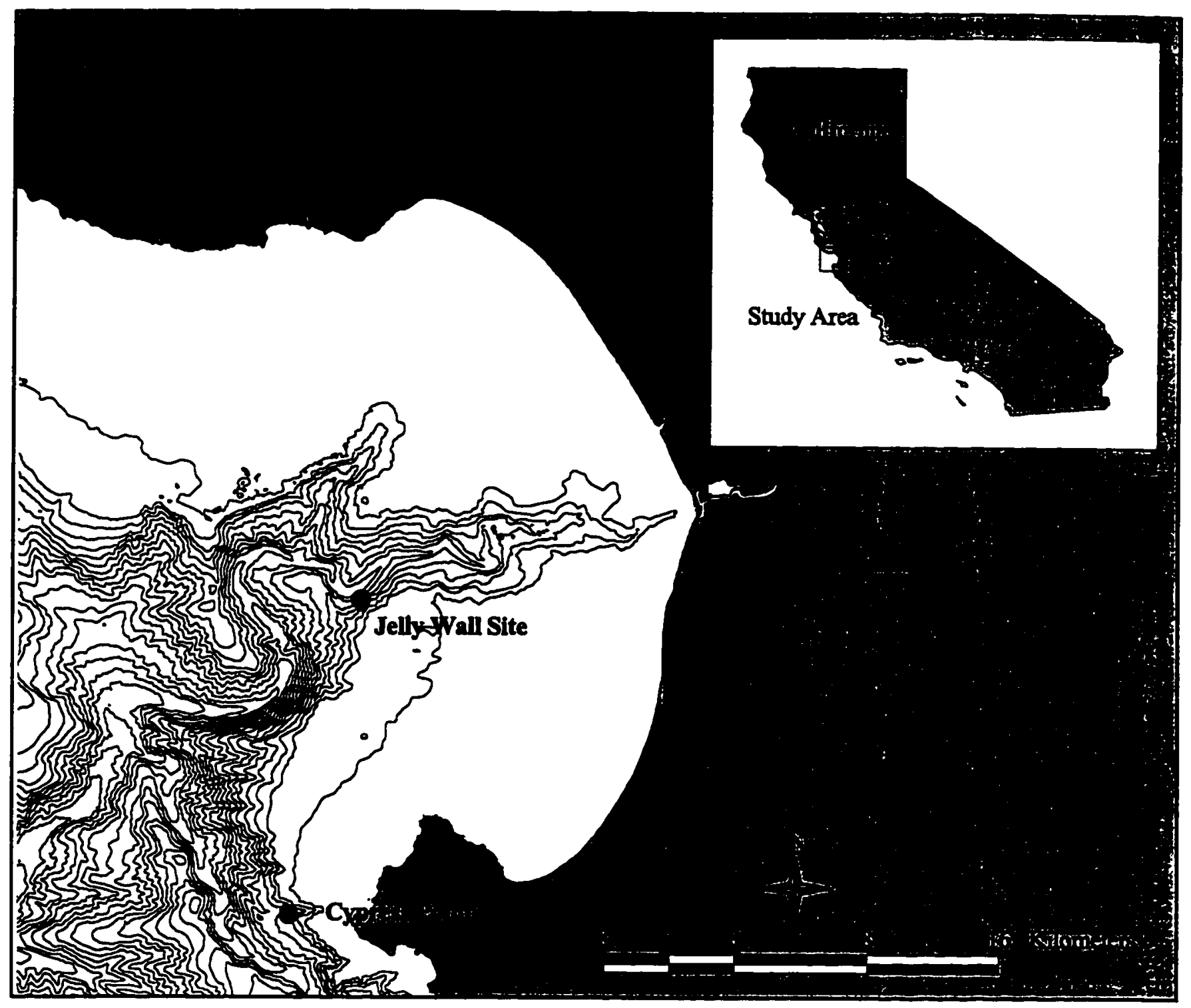

Figure 1. Location of collection sites in Monterey Bay, California, U.S.A. Jelly Wall site in the Monterey Submarine Canyon near Soquel Canyon ( $36^{\circ} 45^{\prime} 22^{\prime \prime} \mathrm{N}$, $121^{\circ} 58^{\prime} 18^{\prime \prime}$ W) at approximately $450 \mathrm{~m}$ depth. Cyress Point site of fshore of Cypress Point, Carmel (36 $34^{\prime} 59^{\prime \prime} \mathrm{N}, 122^{\circ} 00^{\prime} 39^{\prime \prime}$ W) at $300 \mathrm{~m}$ depth. Depth contours shown are $100 \mathrm{~m}$. 

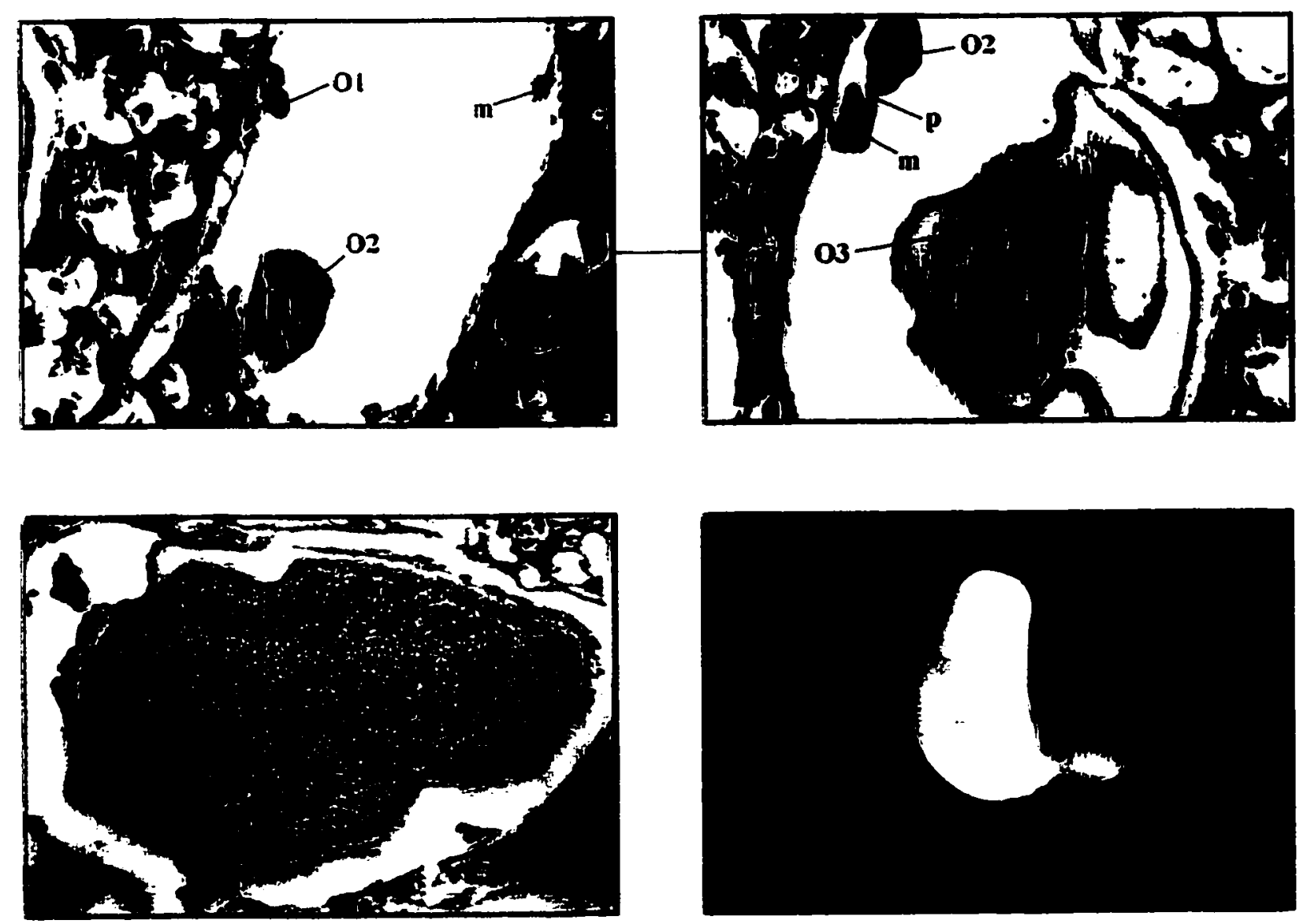

Figure 2. Female reproductive structures of Anthomastus ritteri. A. Stage I oocytes embedded in mesentery and stage II oocyte connected to mesentery (200X). B. Stage II oocyte connected to mesentery by short pedicel and stage III oocytes with large nuclei (200X). C. Stage IV mature oocyte with pink yolk droplets ( $100 \mathrm{X})$. D. Planula larva of A. ritteri (40X). m: mesentery, Ol: stage I oocyte, O2: stage II oocyte, O3: stage III oocyte, O4: stage IV oocyte, p: pedicel. 

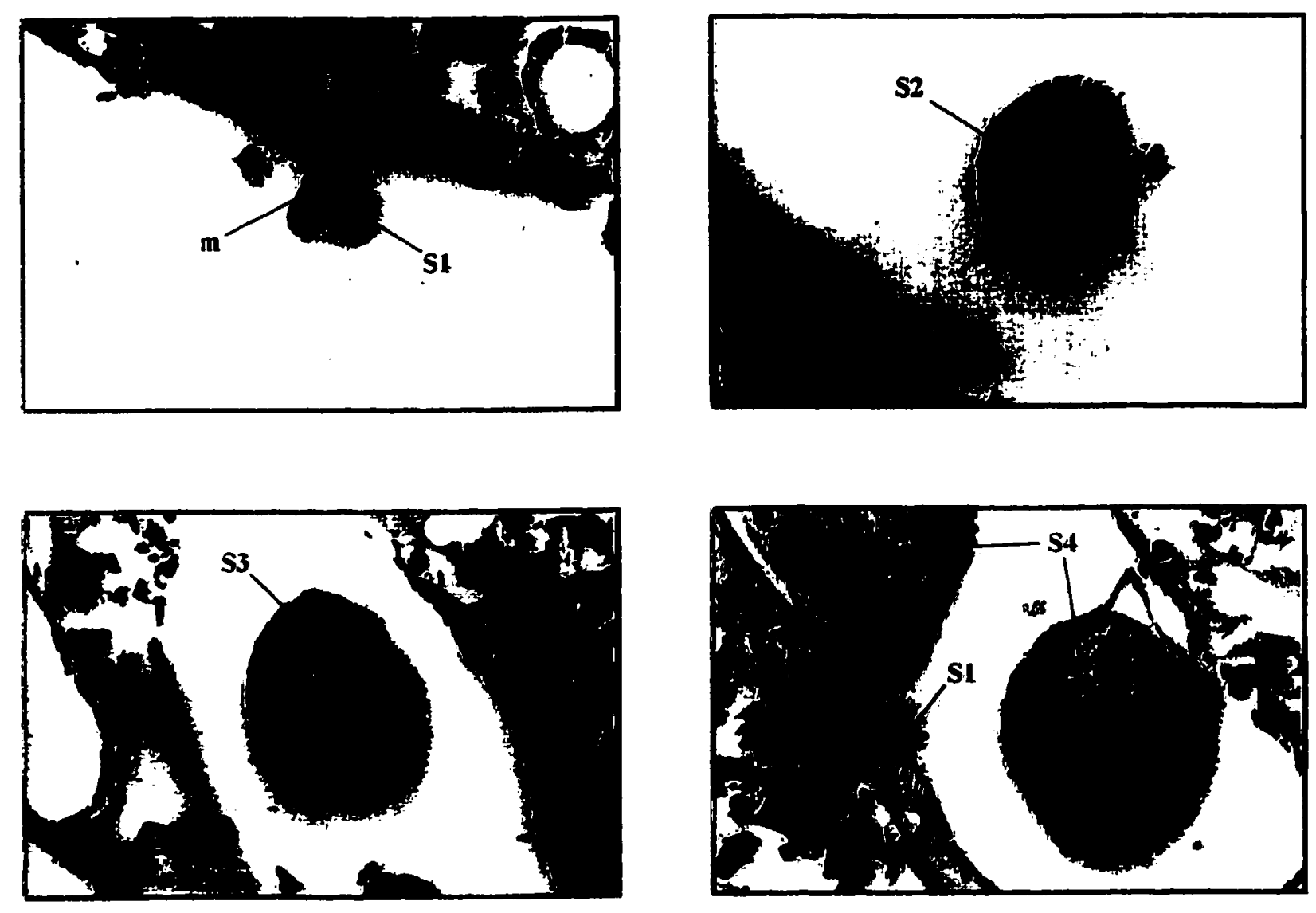

Figure 3. Male reproductive structures of Anthomastus ritteri. A. Stage I spermaries embedded in mesentery $(400 X)$. B. Stage II spermary containing spermatocytes (200X). C. Stage III spermary containing spermatids (200X). D. Stage IV spermaries with mature spermatozoa and small stage I spermaries embedded in mesentery (200X). m: mesentery, S L: stage I spermary, S2: stage II spermary, S3: stage III spermary, S4: stage IV spermary. 

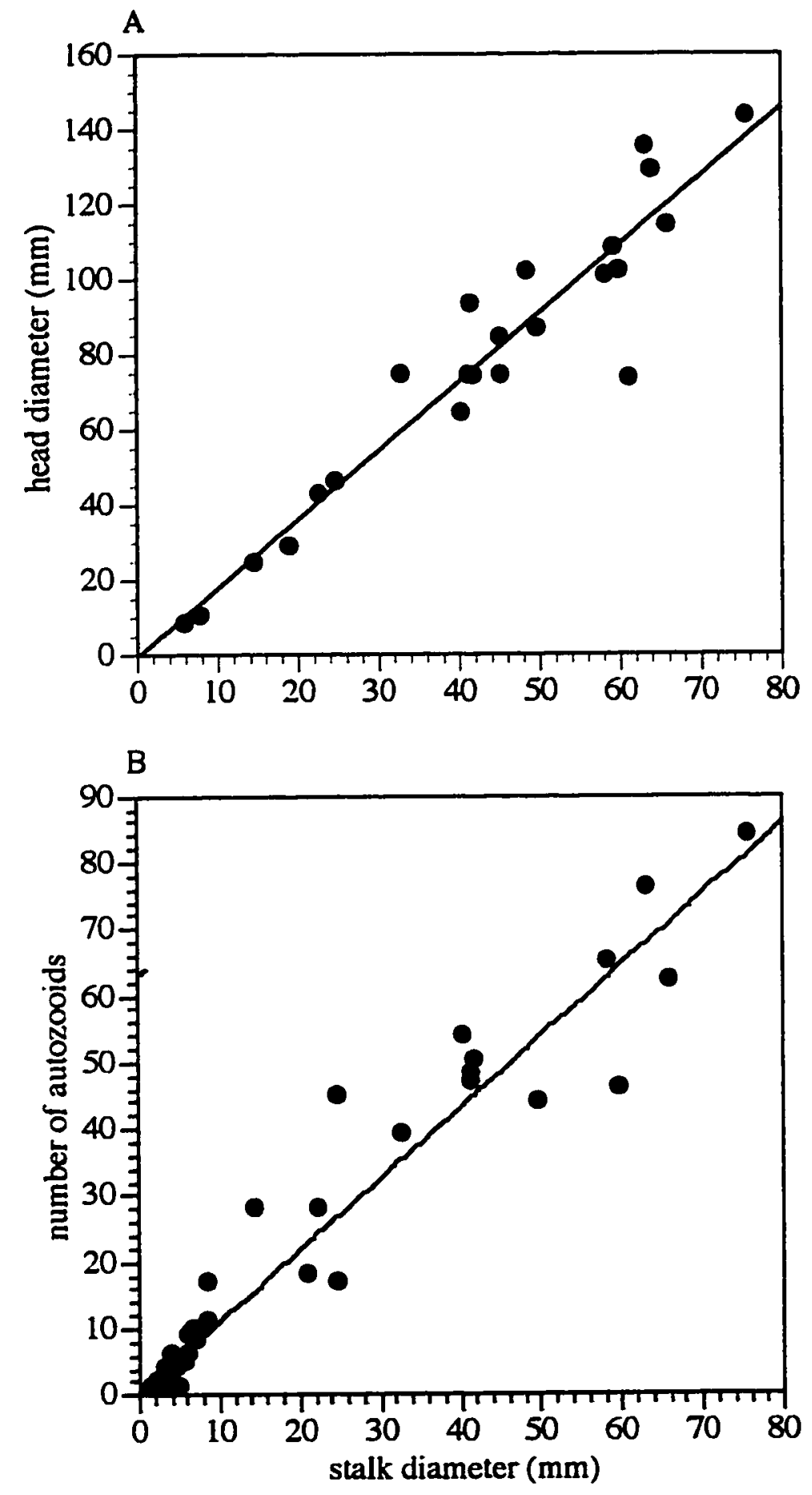

Figure 4. Regression of stalk diameter to other morphological parameters measured. 4a. Relationship with capitulum diameter. $y=1.83 x-0.563, r^{2}=0.903$

4b. Relationship with number of autozooids in colony. $y=1.07 x+0.395, r^{2}=0.937$ 

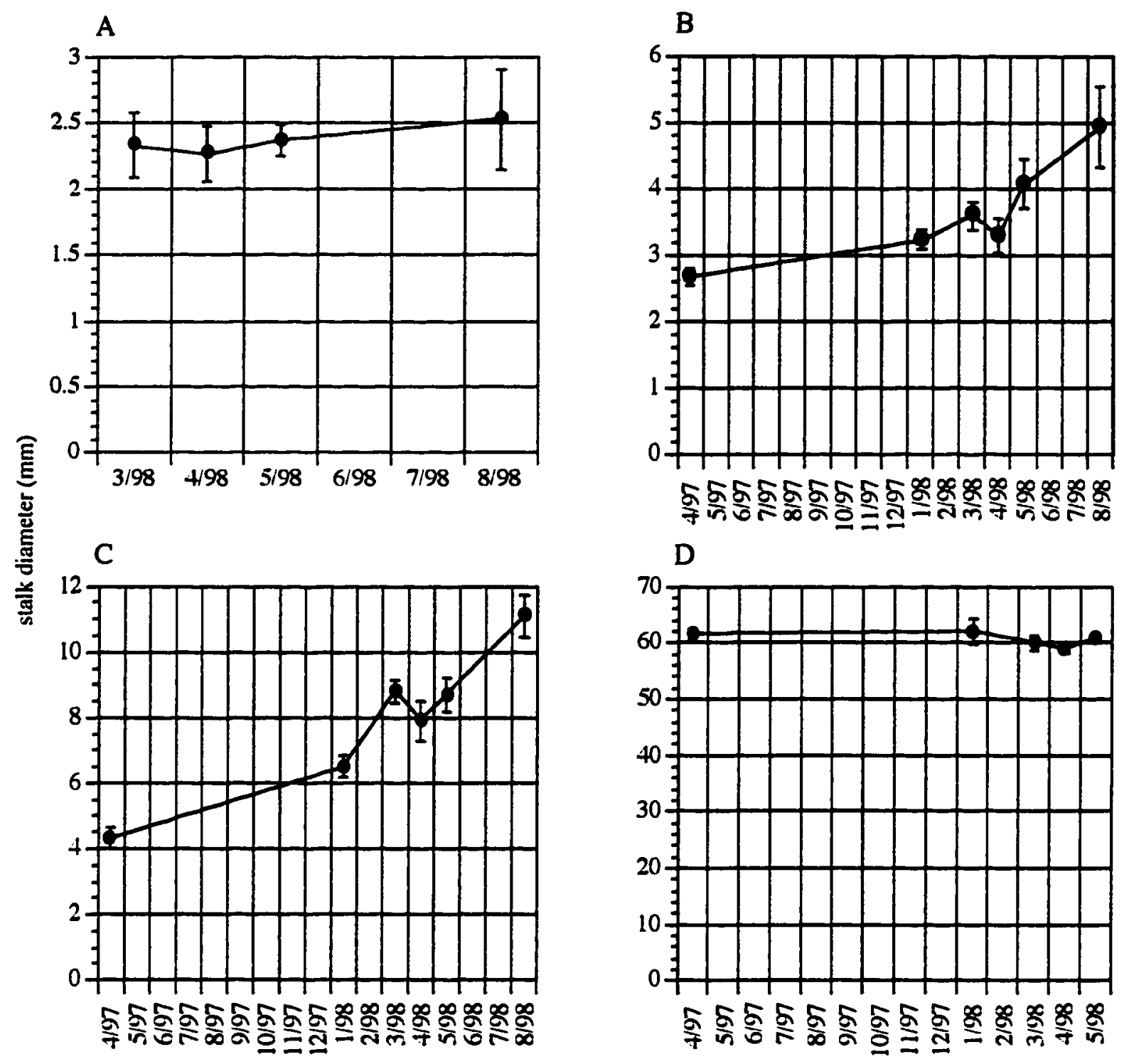

Figure 5. Change in size over time for four representative Anthomastus ritteri colonies. Size data shown are stalk diameters (mm) with error bars representing standard deviation. 


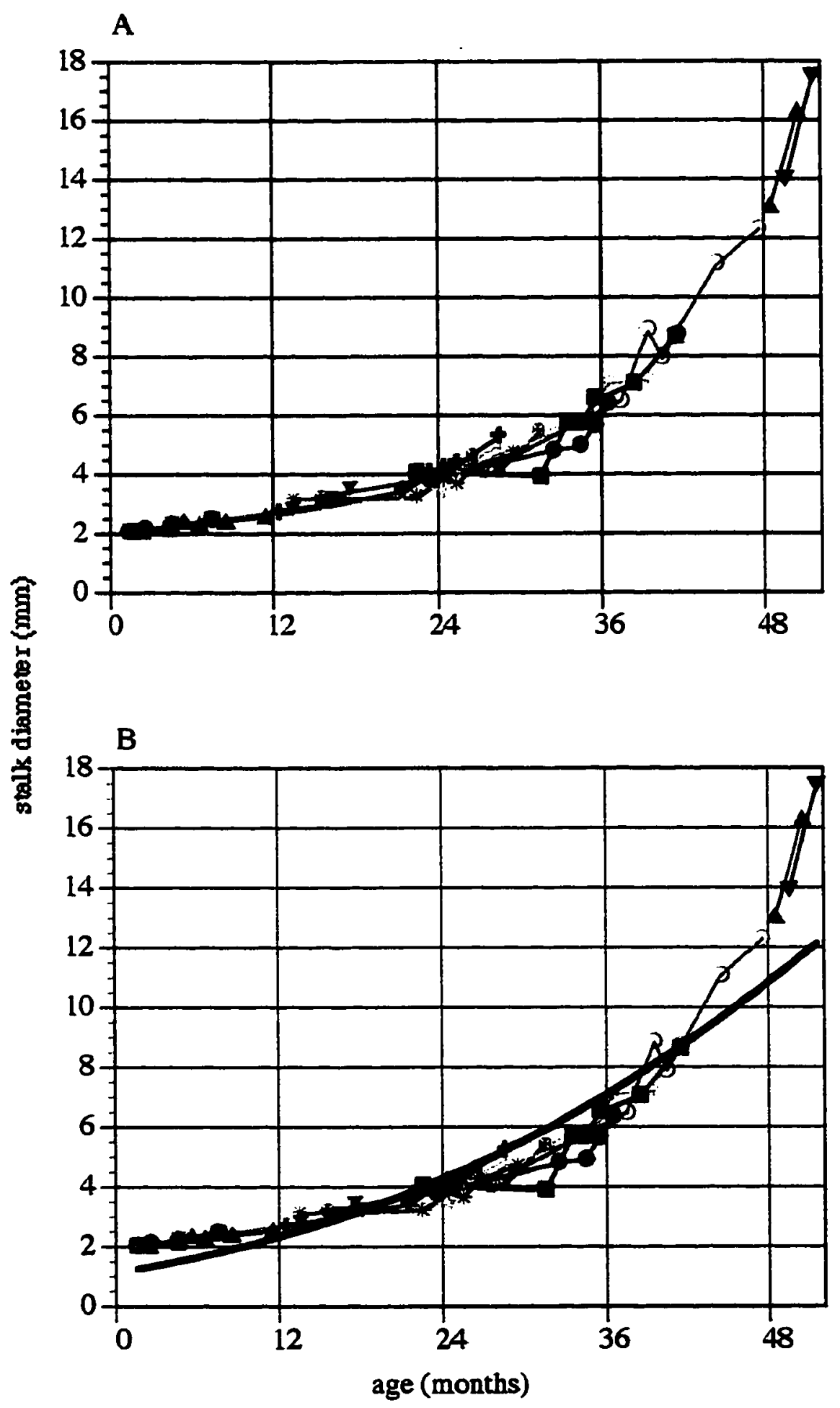

Figure 7. Composite growth chart of 15 Anthomastus ritteri colonies based on size specific growth rate. Overlay on $15 b$ is Gompertz function based on these data. See text for details. 


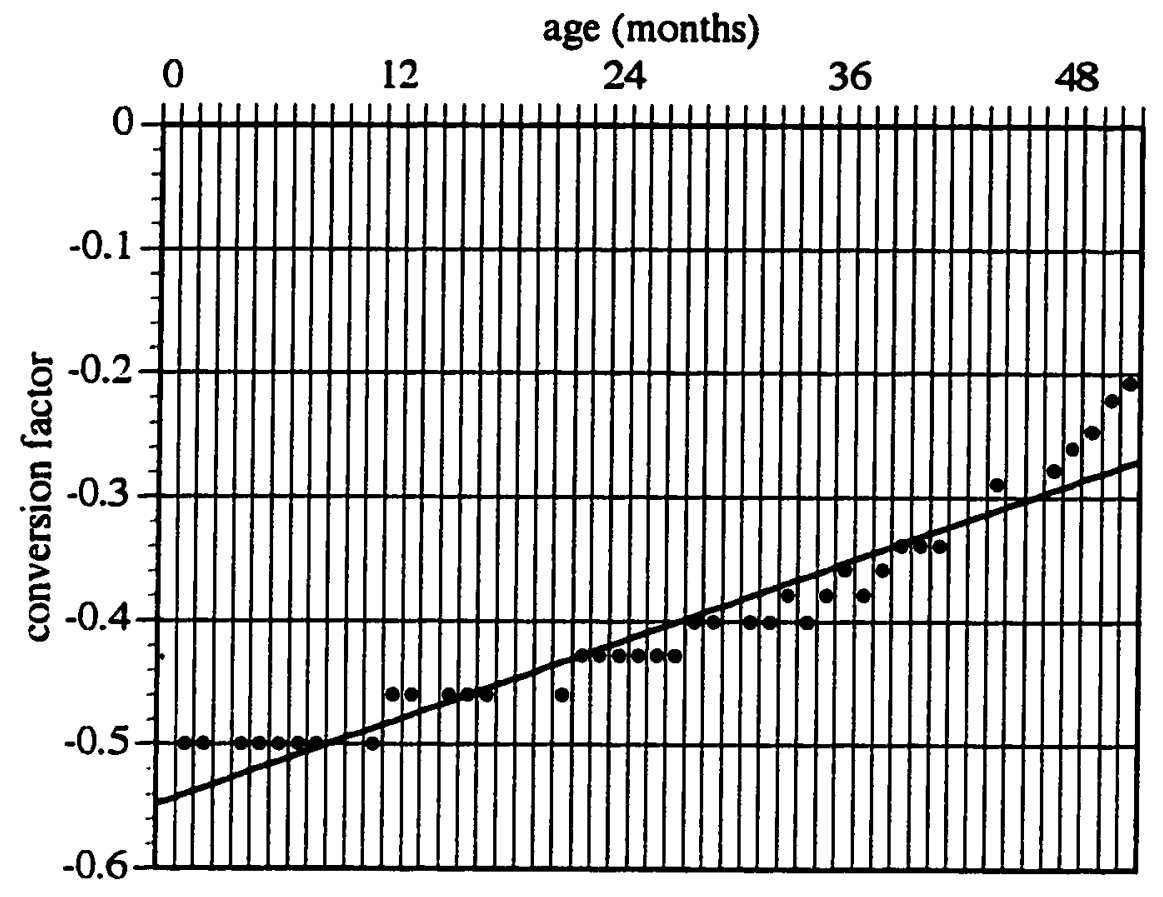

Figure 7. Conversion factors for derivation of Gompertz parameters. Conversion factor based on ratio of size at age to asymptotic stalk diameter (102 mm) (Ricker 1979).

$$
f(x)=0.00535 x-0.551, r^{2}=0.915
$$



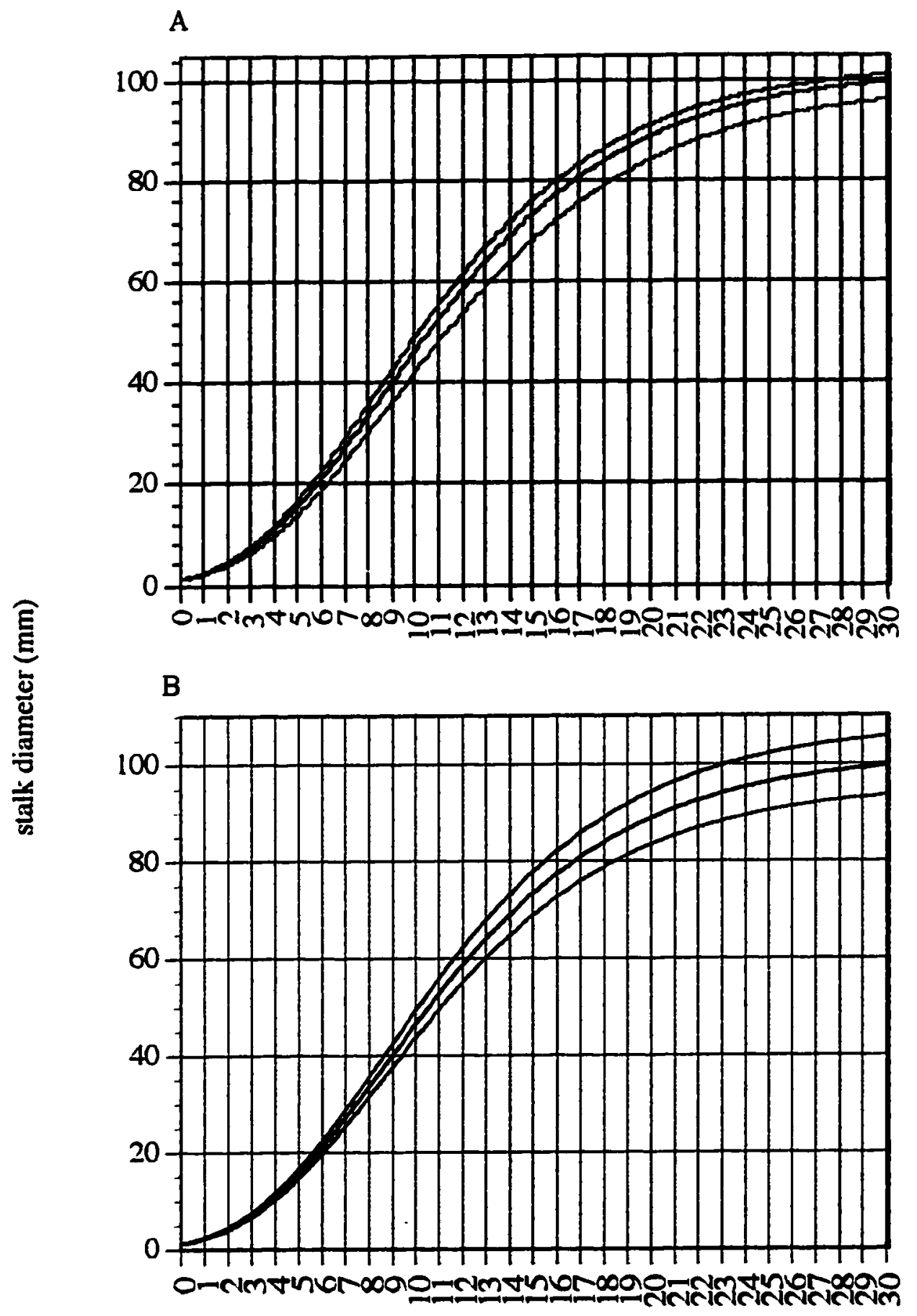

time after metamorphosis (years)

Figure 8. Gompertz growth functions. Stalk diameter described by the function $l=L e^{-e^{\wedge} g(t-t 0)}$ where $\mathrm{l}=$ stalk diameter $(\mathrm{mm})$ at time $\mathrm{t}, \mathrm{L}=$ asymptotic size $(\mathrm{mm}), \mathrm{g}=$ instantaneous rate of growth (mm per month) when $t=t_{0}, t_{0}=$ time at inflection point (months). Average growth curves shown in $8 \mathrm{a}$ and $8 b$ bave the following parameters: $L=102, g=0.0145, t_{0}=103.0$. Error in 8a expressed as additional Gompertz functions based on variability in growth rate. Rapid growth (positive error): $L=103, g=0.0150, t_{0}=99.5$. Slow growth (negative error): $L=99, g=0.0139, t_{0}=108.2$. Error in $8 b$ based on measurement error $($ se $=0.061$ ). 